\title{
INVENTARISASI MAKROINVERTEBRATA BENTIK DI SUNGAI MENTUKA KABUPATEN SEKADAU KALIMANTAN BARAT
}

\author{
Paulus Sangau ${ }^{1}$, Junardi ${ }^{1}$, Diah Wulandari Rousdy ${ }^{1}$ \\ ${ }^{1}$ Program Studi Biologi, Fakultas MIPA, Universitas Tanjungpura, \\ Jl. Prof. Dr. H. Hadari Nawawi, Pontianak, 78124 \\ email korespondensi : paulus4008@gmail.com
}

\begin{abstract}
The existence of Ephemeroptera, Plecoptera and Trichoptera (EPT) macroinvertebrates in water can be used as the indicators to identify the water quality. This study aims to determine the diversity of Macroinvertebrates and physical and chemical factors in water of the Mentuka River. Macroinvertebrate sampling was carried out in February 2018 using random with surber and dip net at three stations spread over the upstream, middle and downstream of the Mentuka River. The measurements chemicals and physical factors such as water temperature, brightness, current velocity, depth, TDS, TSS, acidity ( $\mathrm{pH})$, dissolved oxygen (DO) and free carbon dioxide $\left(\mathrm{CO}_{2}\right)$, which is carried out together with macroinvertebrates sampling. There are 378 macroinvertebrates individuals belonging to nine genera, namely Polypedilum, Hydropsyche, Anthopotamus, Baetis, Acroneuria, Libellula, Rhyacophila, Parathelphusa and Macrobrachium in Mentuka River. The Ephemeroptera, Baetis is the most abundance with 5.76 ind $/ \mathrm{m}^{2}$. Based on the diversity index, the Mentuka was categorized as moderately polluted river.
\end{abstract}

Keywords: Macroinvertebrates, Mentuka River, Baetis, Pantok Village, Sekadau

\section{PENDAHULUAN}

Sungai merupakan suatu aliran air yang mengalir secara alami dan selalu berubah dari waktu ke waktu. Air yang mengalir akan menyebabkan bagian dasar sungai terdegradasi sepanjang waktu. Hasil dari degradasi dapat berupa tanah, pasir dan materi organik yang terbawa arus dari hulu kemudian akan tertumpuk di bagian hilir sungai. Penumpukan sedimentasi dan bahan organik tersebut dapat menyebabkan gangguan terhadap ekosistem pada bagian hilir sungai (Suhardjo, 2008).

Bahan organik yang masuk ke badan sungai juga dapat menyebabkan penurunan kualitas fisika dan kimia sehingga air menjadi tercemar. Perubahan kualitas air akan memengaruhi kehidupan biota di dalamnya. Biota yang akan terganggu akibat adanya pencemaran air, salah satunya adalah kelompok makroinvertebrata. Kelompok fauna ini dapat berupa bentos dan perifiton. Indikasi adanya pencemaran dapat ditandai adanya perubahan keanekaragaman. Keanekaragaman jenis Invertebrata yang tinggi di suatu perairan menandakan perairan tersebut memiliki kualitas yang baik. Keanekaragaman makroinvertebrata yang rendah umumnya menandakan perairan berkualitas buruk atau tercemar (Ratih et al., 2015).

Hasil penelitian sebelumnya yang dilakukan oleh Yeanny, (2010) di aliran Sungai Belawan Medan Sumatera Utara mendapatkan nilai keanekaragaman makrozoobentos tergolong rendah $H(<1)$. Nangin, et al. (2015) di perairan Sungai Suhuyon Sulawesi Utara mendapatkan nilai keanekaragaman makrozoobentos tergolong sedang H (>1-3), Sementara itu, Purwati, (2015) yang melakukan penelitian di aliran Sungai Cisadane Provinsi Jawa Barat dan Banten mendapatkan nilai keanekaragaman makrozoobentos tergolong tinggi (>3).

Hasil penelitian yang terkait dengan nilai keanekaragaman yang dilakukan oleh Yeanny (2010) pada sungai yang tercemar berat, Makroinvertebrata yang ditemukan sebanyak sepuluh Ordo yang didominansi oleh Basommatophora (Moluska). Penelitian lain juga menemukan Makroinvertebrata pada sungai tercemar sedang sebanyak sepuluh Ordo yang didominansai oleh Trichoptera (Insekta) (Nangin, et al. 2015). Makroinvertebrata yang ditemukan pada sungai yang tidak tercemar sebanyak delapan Ordo yang didominansi oleh Trichoptera (Insekta), (Purwati, 2015). Makroinvertebrata yang ditemukan di Sungai Aimasi Kabupaten 
Manokwari sebanyak enam Ordo tanpa adanya Dominansi dengan Indeks Dominansi C $(0,15)$ (Leatemia, et al, 2016). Makroinvertebrata yang ditemukan di Sungai Cokro Malang sebanyak enam Ordo yang didominansi oleh Lymnaedae dan Thiaridae dengan indeks (Moluska dominansi C $(0,59)$ (Maula, 2018). Hal ini menunjukan semakin tinggi tingkat pencemaran akan ditemukan adanya tingkat dominansi yang tinggi.

Sungai Mentuka terletak di Desa Pantok Kecamatan Nanga Taman Kabupaten Sekadau. Sungai Mentuka mempunyai peran penting bagi masyarakat di sekitarnya karena dimanfaatkan sebagai sumber air, Pembangkit Listrik Tenaga Air (PLTA) dan sebagai obyek wisata. Pemanfaatan Sungai Mentuka untuk berbagai kepentingan masyarakat khususnya masyarakat Desa Pantok dapat menyebabkan penurunan kualitas air. Penurunan kualitas sungai ini dapat diketahui dengan perubahan fisik kimia dan biologis air. Data tentang Sungai Mentuka untuk sementara ini belum banyak tersedia. Penelitian yang dilakukan oleh Kristianti et al, (2017) mengamati keanekaragaman jenis ikan. Penelitian tentang Makroinvertebrata sampai saat ini belum pernah dilakukan. Minimnya informasi ilmiah tentang sungai ini menjadi faktor penting untuk melakukan penelitian ini.

Penelitian ini bertujuan untuk mendapatkan data keanekaragaman dan komposisi genus makroinvertebrata di Sungai Mentuka.

\section{BAHAN DAN METODE}

\section{Waktu dan Tempat}

Penelitian ini dilaksanakan pada bulan Februari sampai dengan Maret 2018. Pengambilan sampel Makroinvertebrata di Sungai Mentuka Desa Pantok Kecamatan Nanga Taman Kabupaten Sekadau. Proses identifikasi dilakukan di Laboratorium Zoologi Fakultas Matematika dan Ilmu Pengetahuan Alam Universitas Tanjungpura Pontianak.

\section{Deskripsi Lokasi}

Sungai Mentuka termasuk dalam wilayah Kecamatan Nanga Taman. Luas wilayah kecamatan ini sekitar $1084,68 \mathrm{~km}^{2}$, dengan posisi geografis pada $0^{\circ} .18^{\prime} .28^{\prime \prime}-0^{\circ} .16^{\prime} .58^{\prime \prime}$ Lintang Selatan dan $110^{\circ} .48^{\prime} 43^{\prime \prime}$ Bujur Timur. Batas Kecamatan lain sebagai berikut: Kecamatan Nanga Taman memiliki batas-batas wilayah yaitu bagian utara berbatasan dengan Kecamatan Sekadau Hulu, sebelah timur berbatasan dengan Kecamatan
Sepauk Kabupaten Sintang, sebelah selatan berbatasan dengan Kecamatan Nanga Mahap dan Kecamatan Hulu Sungai (pemekaran Kecamatan Sandai) dan sebelah barat berbatasan dengan Kecamatan Meliau dan Kecamatan Kapuas Kabupaten Sanggau.

Sungai Mentuka terletak di Desa Pantok Kecamatan Nanga Taman, Desa Pantok terletak diantara Desa Keyaya, Kenatak, Kenabu dan Biana (Gambar 1). Sungai Mentuka memiliki kecepatan arus rata-rata 2 m/dt (Dinas LH Sekadau, 2008) dan memiliki substrat hamparan batuan besar di sepanjang sungai, sedangkan substrat lunak atau substrat berpasir ditemukan di bagian hilir sungai ini. Lokasi penelitian disajikan pada Gambar 1.

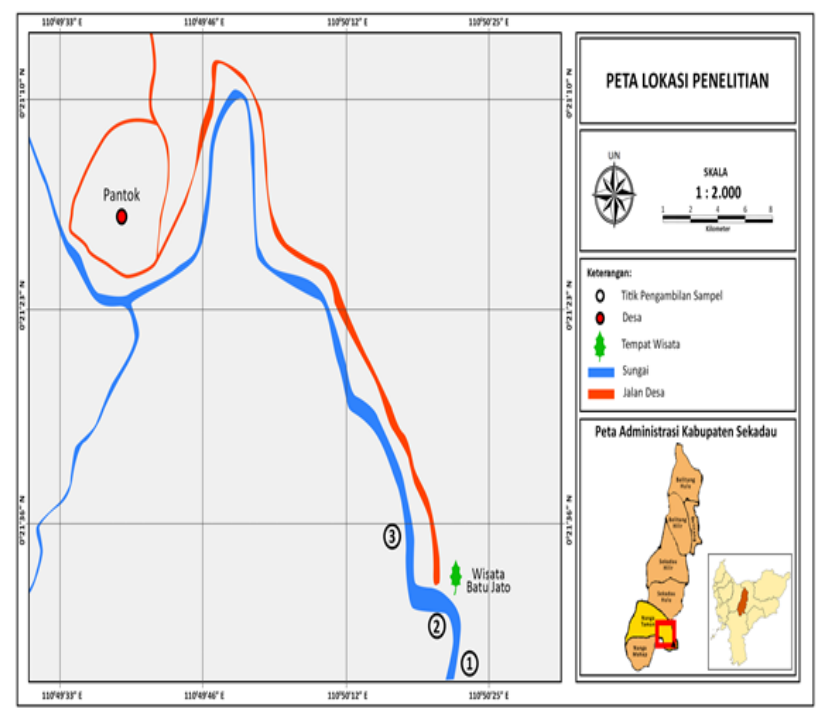

Gambar 1. Peta Lokasi Penelitian

\section{Alat dan Bahan}

Alat-alat yang digunakan untuk pengambilan sampel Makroinvertebrata adalah jala Surber, kantong plastik, saringan dengan ukuran mata saring $0,5 \mathrm{~mm}$, wadah plastik, kuas kecil, sikat, botol sampel, label, spidol, kertas $\mathrm{pH}$ universal, tongkat berskala, termometer, mikroskop stereo Euromex Arnhem 171875, lup, erlenmeyer $100 \mathrm{ml}$, botol winkler, pipet tetes, spuit, termometer air raksa, stopwatch, kertas $\mathrm{pH}$, kertas saring, keping Secchi, bola pimpong dan GPS (Global Positioning System) Garmin eTrex 30 dan serokan.

Bahan-bahan yang digunakan adalah formalin $4 \%$, akuades, mangan sulfat $\left(\mathrm{MnSO}_{4}\right)$, natrium karbonat $\left(\mathrm{Na}_{2} \mathrm{CO}_{3}\right)$, natrium tiosulfat $\left(\mathrm{Na}_{2} \mathrm{~S}_{2} \mathrm{O}_{3}\right)$, kalium hidroksida $(\mathrm{KOH})$, kalium iodida (KI), amilum $\left(\mathrm{C}_{6} \mathrm{H}_{10} \mathrm{O}_{5}\right)$, indikator fenolpthaelin $0,5 \%$ dan alkohol $70 \%$ 


\section{Penentuan Stasiun}

Penentuan stasiun pengambilan sampel berdasarkan rona lingkungan. pengambilan sampel dengan metode purposive random sampling dan

menetapkan tiga stasiun berdasarkan rona lingkungan (Tabel 1).

Tabel 1. Deskripsi lokasi penelitian

\begin{tabular}{|c|c|c|}
\hline Stasiun & Titik Koordinat & Rona Lingkungan \\
\hline I (Hulu) & $\begin{array}{l}00^{\circ} 21^{\prime} 90,1^{\prime \prime} \mathrm{LS} \\
110^{\circ} 50^{\prime} 45,7^{\prime \prime} \mathrm{BT}\end{array}$ & $\begin{array}{l}\text { kondisi substrat berbatu besar, terdapat area perkebunan, berbatasan } \\
\text { dengan lubuk kijing. Rata-rata kedalaman air } \pm 120 \mathrm{~cm}\end{array}$ \\
\hline II (Tengah) & $\begin{array}{l}00^{\circ} 21^{\prime} 81,7^{\prime \prime} \mathrm{LS} \\
110^{\circ} 50^{\prime} 39.7^{\prime \prime} \mathrm{BT}\end{array}$ & $\begin{array}{l}\text { Kondisi substrat berbatu, area wisata, terdapat rumah penduduk dan } \\
\text { bendungan air yang digunakan untuk Listrik tenaga air. Rata-rata } \\
\text { kedalaman air } \pm 130 \mathrm{~cm}\end{array}$ \\
\hline III (Hilir) & $\begin{array}{ll}00^{\circ} 21^{\prime} 38^{\prime \prime} & \text { LS } \\
110^{\circ} 50^{\prime} 17^{\prime \prime} & \text { BT }\end{array}$ & Kondisi substrat dilokasi berbatu. Rata-rata kedalaman air $\pm 120 \mathrm{~cm}$ \\
\hline
\end{tabular}

Pengambilan Sampel Makroinvertebrata

Pengambilan sampel Makroinvertebrata dilakukan di sisi kiri, tengah dan kanan sungai. Pengambilan sampel sebanyak tiga titik pada masing-masing stasiun. Sampel diambil dari dalam plot berukuran $1 \mathrm{x} 1 \mathrm{~m}^{2}$. Pengambilan sampel dilakukan dengan menggunakan jala Surber untuk substrat keras. Jala Surber diletakan di atas substrat dengan posisi mulut jala berlawanan arah dengan arus air. Pada substrat lunak sampel diambil menggunakan serokan dengan ukuran mata saring 0,5 mm. Pada setiap stasiun, sampel diambil sebanyak tiga kali pada bagian tepi kiri, tengah dan kanan. Total sampel pada masing-masing stasiun sebanyak Sembilan sempel, sehingga jumlah sampel pada keseluruhan stasiun sebanyak 27 sampel. Sampel dimasukan ke dalam nampan dan disortir, kemudian diawetkan dengan formalin $4 \%$ dan diberi label.

\section{Pengukuran Faktor Fisika-Kimia Air}

Pengukuran faktor fisika-kimia perairan dilakukan bersamaan dengan pengambilan sampel Makroinvertebrata. Faktor fisika yang diukur adalah Kecepatan arus diukur dengan bola pimpong, tongkat bersekala dan stopwatch. Suhu air diukur menggunakan termometer air raksa. Kecerahan diukur dengan keping Secchi, kedalaman diukur dengan tongkat bersekala. Pengambilan sampel air untuk pengukuran Total Dissolved Solid (TDS) dan Total Suspended Solid (TSS), sampel dimasukan ke dalam botol kaca 50 $\mathrm{ml}$, sampel diuji menggunakan metode gravitmetri dengan disaring menggunkan kertas saring yang sudah dioven selama satu jam dengan suhu $105^{\circ} \mathrm{C}$
(Rinawati, et al., 2016). Pengujian dilakukan di Laboratorium Zoologi Fakultas MIPA Universitas Tanjungpura.

Faktor kimia yang di ukur adalah derajat keasaman diukur menggunakan $\mathrm{pH}$ meter, oksigen terlarut dan karbondioksida bebas dengan titrasi modifikasi Winkler, sampel air diambil menggunakan botol Winkler (Salmin, 2005).

\section{Identifikasi}

Identifikasi makroinvertebrata dilakukan dengan bantuan mikroskop sampai tingkat genus dengan mengamati karakter morfologi meliputi bentuk kepala, jumlah segmen, bentuk ekor, jumlah percabangan pada ekor, ada tidaknya antena, bentuk gigi dan ada tidaknya sayap. Identifikasi menggunakan buku acuan, Needham dan Needham (1964) dan Cummins (1975).

\section{Analisis Data}

Analisis data meliputi kelimpahan (K), kelimpahan relatif (KR), frekuensi kehadiran (FK), indeks keragaman Shanon Wiener $\left(\mathrm{H}^{\prime}\right)$, indeks kemerataan Pielou (E), indeks Dominansi Simpson (C).

\section{Kelimpahan}

Kelimpahan $=\frac{\text { Jumlah Individu Suatu genus }}{\text { Luas Unit Sampel }(1 \mathrm{~m} \mathrm{x} 1 \mathrm{~m})}$

(Michael, 1984)

Klasifikasi tingkat kelimpahan spesies jika angka $\mathrm{K}\left(\mathrm{Ind} / \mathrm{m}^{2}\right)=0$ maka tidak ditemukan individu yang melimpah. Jika $\mathrm{K}=0$-200 dikatakan tidak melimpah. Jika $\mathrm{K}=200-500$ dikatakan melimpah 
sedang. Jika $\mathrm{K}=500-1000$ dikatakan melimpah dan jika $\mathrm{K}=>1000$ maka dikatakan sangat melimpah (Michael, 1984).

\section{Kelimpahan Relatif}

$$
\mathrm{KR}=\frac{\mathrm{ni}}{\mathrm{N}} \times 100 \%
$$

Keterangan: $\mathrm{KR}=$ Kelimpahan Relatif

$$
\begin{aligned}
& \mathrm{Ni}=\text { Jumlah Individu Genus Ke-i } \\
& \mathrm{N}=\text { Jumlah Seluruh Individu }
\end{aligned}
$$

\section{Frekuensi Kehadiran}

(Odum, 1993)

$\mathrm{FK}=\frac{\text { Jumlah kehadiran Suatu Genus }}{\text { total kehadiran }} \times 100 \%$

\section{Indeks Shanon Wiener}

(Michael, 1984)

$$
\mathrm{H}^{\prime}=-\sum_{\mathrm{n}=1}^{\mathrm{n}} \mathrm{pi} \ln \mathrm{pi}
$$

$$
\begin{array}{ll}
\text { Keterangan : } & \mathrm{H}^{\prime}=\text { Indeks Keanekaragaman } \\
& \mathrm{pi}=\mathrm{ni} / \mathrm{N} \\
& \mathrm{ni}=\mathrm{Jumlah} \text { Individu Genus ke-i } \\
& \mathrm{N}=\text { Jumlah Total Individu }
\end{array}
$$

(Odum, 1993).

Klasifikasi tingkat keanekaragamannya jika nilai $\mathrm{H}^{\prime}=<1$ maka tinckat keanekaracamannva rendah, jika

keanekaragama

maka tingkat $\mathrm{kt}$

(Odum, 1993).

\section{Indeks Dominansi Simpson}

$$
\mathrm{C}=\sum(\mathrm{pi})^{2}
$$

$$
\begin{array}{ll}
\text { Keterangan : } & \mathrm{C}=\text { Indeks Dominansi } \\
& \mathrm{pi}=\mathrm{ni} / \mathrm{N}
\end{array}
$$

$$
\text { ni = Jumlah Individu Genus ke-i }
$$$$
\mathrm{N}=\text { Jumlah Total Individu }
$$

(Odum, 1993).

Klasifikasi indeks Dominansi yaitu : $0<\mathrm{C} \leq 0,5=$ tidak ada genus yang mendominasi dan jika $0,5<$ $\mathrm{C}<1=$ terdapat genus yang mendominasi Munthe, et al.,(2012).

\section{Indeks Kemerataan Pielou}

$$
\mathrm{E}=\frac{\mathrm{H}^{\prime}}{\log \mathrm{S}}
$$

$$
\begin{array}{cl}
\text { Keterangan: } & \mathrm{E}=\text { Indeks Kemerataan } \\
& \mathrm{H}^{\prime}=\text { Indeks Keanekaragaman } \\
& \mathrm{S}=\text { Jumlah Genus pada Setiap } \\
& \text { Stasiun }
\end{array}
$$

Klasifikasi tingkat kemerataan yaitu jika nilai indeks kemerataannya $<0,4$ tingkat kemerataanya rendah, jika nilai indeks kemerataannya 0,4-0,6 maka tingkat kemerataanya sedang dan jika nilai indeks kemerataannya $>0,6$ maka tingkat kemerataanya tinggi (Odum, 1993).

\section{HASIL DAN PEMBAHASAN}

\section{Komposisi dan Jumlah Individu Genus Makroinvertebrata di Sungai Mentuka \\ Makroinvertebrata yang ditemukan di} Sungai Mentuka Desa Pantok Kecamatan Nanga Taman terdiri atas sembilan famili dan genus. Famili dan genus yang ditemukan adalah Chironomidae (Polypedilum), Hydropsychidae (Hydropsyche), Potamanthidae (Anthopotamus), Baetidae (Baetis), Perlidae (Acroneuria), Libellulidae (Libellula), Rhyacophilidae (Rhyacophila), Gecarcinucidae (Parathelphusa), Palaemonidae (Macrobrachium). Komposisi makroinvertebrata yang ditemukan selama penelitian disajikan pada Tabel 2 . 
Tabel .2 Komposisi dan Jumlah Individu Makroinvertebrata di Sungai Mentuka

\begin{tabular}{|c|c|c|c|c|c|c|c|}
\hline \multirow{2}{*}{ No } & \multirow{2}{*}{ Taksa } & \multirow{2}{*}{ Famili } & \multirow{2}{*}{ Genus } & \multicolumn{3}{|c|}{ Jumlah Individu } & \multirow{2}{*}{ Total } \\
\hline & & & & S1 & S2 & $\mathbf{S 3}$ & \\
\hline & $\begin{array}{l}\text { Kelas Insekta } \\
\text { Ordo }\end{array}$ & & & & & & \\
\hline 1 & Diptera & Chironomidae & Polypedilum & 19 & 14 & 15 & 48 \\
\hline \multirow[t]{2}{*}{2} & Trichoptera & Hydropsychidae & Hydropsyche & 20 & 10 & 12 & 42 \\
\hline & & Rhyacophilidae & Rhyacophila & 8 & 20 & 10 & 38 \\
\hline \multirow[t]{2}{*}{3} & Ephemeroptera & Potamanthidae & Anthopotamus & 16 & 20 & 13 & 49 \\
\hline & & Baetidae & Baetis & 17 & 14 & 21 & 52 \\
\hline 4 & Plecoptera & Perlidae & Acroneuria & 20 & 6 & 4 & 30 \\
\hline \multirow[t]{3}{*}{5} & Odonata & Libellulidae & Libellula & 14 & 5 & 12 & 31 \\
\hline & Total individu Insekta & & & 114 & 89 & 87 & 290 \\
\hline & $\begin{array}{l}\text { Kelas Krustacea } \\
\text { Ordo }\end{array}$ & & & & & & \\
\hline \multirow[t]{4}{*}{6} & Decapoda & Gecarcinucidae & Parathelphusa & 13 & 10 & 17 & 40 \\
\hline & & Palaemonidae & Macrobrachium & 20 & 16 & 12 & 48 \\
\hline & Total individu Krustacea & & & 33 & 26 & 29 & 88 \\
\hline & & Total & & 147 & 115 & 116 & 378 \\
\hline
\end{tabular}

Keterangan: S1-3 Stasiun 1-3

Makroinvertebrata kelas Insekta ditemukan sebanyak 5 Ordo, 7 Famili dan 7 Genus yaitu Polypedilum, Hydropsyche, Anthopotamus, Baetis, Acroneuria, Libellula, Rhyacophila. Total Insekta yang ditemukan pada Sungai Mentuka sebanyak 290 individu, jumlah yang paling banyak ditemukan pada stasiun 1 dengan total 114 individu atau 39,31\% dari total individu dan yang paling sedikit ditemukan pada stasiun 3 dengan total 87 individu atau $30 \%$ dari total individu.

Genus yang paling banyak ditemukan yaitu Baetis, (Ephemeroptera, Baetidae) yang ditemukan sebanyak 52 individu. Genus ini banyak ditemukan pada stasiun 3 dengan total 21 individu atau $40,38 \%$ dari total individu dan paling sedikit ditemukan pada stasiun 2 dengan total 14 individu atau $27,82 \%$ dari total individu. Genus yang paling sedikit ditemukan yaitu Acroneuria (Plecoptera, Perlidae) dengan total 30 individu. Genus ini paling banyak ditemukan pada stasiun 1 dengan total 20 indivdu atau 67,56\% dari total individu dan paling sedikit ditemukan pada stasiun 3 dengan total 4 individu atau 13,33\% dari total individu.

Makroinvertebrata kelas Krustacea ditemukan sebanyak 1 Ordo, 2 famili dan 2 Genus yaitu Parathelphusa dan Macrobrachium. Total Krustacea yang ditemukan pada Sungai Mentuka sebanyak 88 individu. jumlah yang paling banyak ditemukan pada stasiun 1 dengan total 33 individu atau $37,5 \%$ dari total individu dan yang paling sedikit ditemukan pada stasiun 2 dengan total 26 individu atau 29,54\% dari total individu.

Genus yang paling banyak ditemukan yaitu: Macrobrachium, (Decapoda, Palaemonidae) yang ditemukan sebanyak 48 individu. Genus ini banyak ditemukan pada stasiun 1 dengan total 20 individu atau $42,56 \%$ dari total individu dan paling sedikit ditemukan pada stasiun 3 dengan total 12 individu atau $25 \%$ dari total individu. Genus yang paling sedikit ditemukan yaitu Parathelphusa (Decapoda, Gecarcinucidae) dengan total 40 individu. Genus ini paling banyak ditemukan pada stasiun 3 dengan total 17 individu atau $42,56 \%$ dari total individu dan paling sedikit ditemukan pada stasiun 2 dengan total 10 individu atau $25 \%$ dari total individu.

\section{Kelimpahan (K), Kelimpahan Relatif (KR) dan Frekuensi Kehadiran (FK)}

Kelimpahan Makroinvertebrata yang ditemukan berbeda-beda mulai dari 12,78-16,33 ind $/ \mathrm{m}^{2}$ dengan kelimpahan relatif dan frekuensi kehadiran yang sama besar 100\% (Tabel 3). Kelimpahan tertinggi terdapat pada stasiun 1 dengan nilai $16,33 \mathrm{ind} / \mathrm{m}^{2}$ dan kelimpahan terendah ditemukan pada stasiun 2 dengan nilai kelimpahan $12,78 \mathrm{ind} / \mathrm{m}^{2}$.

Kelimpahan genus makroinvertebrata yang ditemukan di sungai Mentuka memiliki rentang 
dari $0,44 \mathrm{ind} / \mathrm{m}^{2}-2,33 \mathrm{ind} / \mathrm{m}^{2}$. Baetis adalah genus makroinvertebrata yang memiliki kelimpahan tertinggi dengan nilai $2,33 \mathrm{ind} / \mathrm{m}^{2}$ dan Acroneuria genus yang memiliki kelimpahan terendah dengan nilai $0,44 \mathrm{ind} / \mathrm{m}^{2}$.

Kelimpahan relatif makroinvertebrata yang ditemukan di sungai Mentuka memiliki rentang dari $3,44 \%-18,10 \%$. Baetis adalah genus makroinvertebrata yang memiliki kelimpahan relatif tertinggi dengan nilai $18,10 \%$ dan Acroneuria genus yang memiliki kelimpahan relatif terendah dengan nilai 3,44\%. Ketiga stasiun penelitian memilik presentasi frekuensi kehadiran $100 \%$ pada semua genus, yang menandakan semua genus ditemukan pada semua stasiun.

Kelimpahan genus makroinvertebrata tertinggi yang ditemukan pada stasiun 1 ada 3 genus seperti Hydropsyche, Acroneuria dan Macrobrachium dengan nilai kelimpahan yang sama yaitu $2,22 \mathrm{ind} / \mathrm{m}^{2}$ dan kelimpahan genus terendah pada stasiun 1 yaitu Rhyacophila dengan nilai kelimpahan $0,89 \mathrm{ind} / \mathrm{m}^{2}$. Kelimpahan genus tertinggi yang ditemukan pada stasiun 2 ada 2 genus seperti Anthopotamus dan Rhyacophila dengan nilai kelimpahan yang sama yaitu 2,22 ind $/ \mathrm{m}^{2}$ dan kelimpahan genus terendah pada stasiun 2 yaitu Libellula dengan nilai kelimpahan $0,55 \mathrm{ind} / \mathrm{m}^{2}$. Kelimpahan genus tertinggi yang ditemukan pada stasiun 3 yaitun Baetis dengan nilai kelimpahan 2,33 ind $/ \mathrm{m}^{2}$ dan kelimpahan genus terendah yaitu Acroneuria dengan nilai kelimpahan $0,44 \mathrm{ind} / \mathrm{m}^{2}$.

Genus Hydropsyche, Acroneuria dan Macrobrachium memiliki nilai kelimpahan relatif tertinggi pada stasiun 1, ketiga genus tersebut memiliki nilai yang sama yaitu $13,60 \%$ dan genus Rhyacophila memiliki kelimpahan relatif terendah pada stasiun 1 dengan nilai 5,42 \%. Genus Anthopotamus dan Rhyacophila memiliki nilai kelimpahan relatif tertinggi pada stasiun 2, kedua genus tersebut memiliki nilai yang sama yaitu $17,39 \%$ dan genus Libellula memiliki nilai kelimpahan relatif terendah pada stasiun 2 dengan nilai 4,34\%. Genus Baetis memiliki kelimpahan relatif tertinggi pada stasiun 3 dengan nilai 18,10 $\%$ dan genus Acroneuria memiliki kelimpahan relatif terendah pada stasiun 3 dengan nilai $3,44 \%$

Tabel 3. Kelimpahan dan Frekuensi Kehadiran Makroinvertebrata di Sungai Mentuka

\begin{tabular}{|c|c|c|c|c|c|c|c|c|}
\hline \multicolumn{2}{|c|}{ Taksa } & \multicolumn{3}{|c|}{$\mathrm{K}\left(\mathrm{Ind} / \mathrm{m}^{2}\right)$} & \multicolumn{3}{|c|}{ KR $(\%)$} & \multirow{2}{*}{ FK } \\
\hline Famili & Genus & S1 & S2 & S3 & S1 & S2 & S3 & \\
\hline Chironomidae & Polypedilum & 2,11 & 1,55 & 1,67 & 12,92 & 12,17 & 12,93 & 100 \\
\hline Hydropsychidae & Hydropsyche & $2,22^{*}$ & 1,11 & 1,33 & $13,60^{*}$ & 8,69 & 10,34 & 100 \\
\hline Potamanthidae & Anthopotamus & 1,78 & $2,22^{*}$ & 1,44 & 10,88 & $17,39^{*}$ & 11,20 & 100 \\
\hline Baetidae & Baetis & 1,88 & 1,55 & $2,33^{*}$ & 11,56 & 12,17 & $18,10^{*}$ & 100 \\
\hline Perlidae & Acroneuria & $2,22^{*}$ & 0,67 & $0,44^{\prime}$ & $13,60^{*}$ & 5,21 & $3,44^{\prime}$ & 100 \\
\hline Libellulidae & Libellula & 1,55 & $0,55^{\prime}$ & 1,33 & 9,52 & $4,34^{\prime}$ & 10,34 & 100 \\
\hline Rhyacophilidae & Rhyacophila & $0,89^{\prime}$ & $2,22^{*}$ & 1,11 & $5,42^{\prime}$ & $17,39^{*}$ & 8,62 & 100 \\
\hline Gecarcinucidae & Parathelphusa & 1,44 & 1,11 & 1,89 & 8,84 & 8,69 & 14,65 & 100 \\
\hline Palaemonidae & Macrobrachium & $2,22^{*}$ & 1,78 & 1,33 & $13,60^{*}$ & 13,91 & 10,34 & 100 \\
\hline \multicolumn{2}{|c|}{ Jumlah } & 16,33 & 12,78 & 12,89 & 100 & 100 & 100 & \\
\hline
\end{tabular}

Keterangan : Ind (individu), K (Kelimpahan), KR (Kelimpahan Relatif), FK (Frekuensi Kehadiran), S (Stasiun), * ( angka tertinggi), ' (angka terendah).

\section{Indeks Keanekaragaman Indeks Dominansi dan Indeks kemerataan Makroinvertebrata}

Indeks keanekaragaman makroinvertebrata yang ditemukan pada Sungai Mentuka memiliki rentangan nilai $\mathrm{H}^{\prime}(2,11-2,17)$, indeks dominansi makroinvertebrata memiliki rentangan nil ai $\mathrm{C}^{\prime}$ $(0,11-0,13)$ dan indeks kemerataan makroinvertebrata memiliki rentangan nilai $\mathrm{E}^{\prime}$ (2,21-2,270). Keanekaragaman Makroinvertebrata yang tertinggi ditemukan di Sungai Mentuka terdapat pada stasiun1 dengan nilai indeks keanekargaman $\quad \mathrm{H}^{\prime} \quad(2,17)$ dan indeks keanekaragaman terendah terdapat pada stasiun kedua dengan nilai indeks keanekaragamannya $\mathrm{H}^{\prime}$ $(2,11)$. Indeks dominansi, tertinggi terdapat pada stasiun 2 dengan nilai indeks dominansi $\mathrm{C}^{\prime}(0.13)$ dan indeks dominansi terendah ditemukan pada stasiun 1 dengan nilai indeks dominansi $\mathrm{C}^{\prime}(0.11)$. Indeks kemerataan tertinggi ditemukan pada stasiun 1 dengan nilai indeks kemerataanya $E^{\prime}$ $(2,27)$ dan nilai indeks kemerataan terendah ditemukan pada stasiun 2 dengan nilai indeks kemerataannya $E^{\prime}(2,21)$ seperti pada Tabel 4 
Tabel 4. Indeks Keanekaragaman Makroinvertebrata di Sungai Mentukaa

\begin{tabular}{cccc}
\hline Stasiun & $\left(\mathbf{H}^{\prime}\right)$ & $\left(\mathbf{C}^{\prime}\right)$ & $\left(\mathbf{E}^{\prime}\right)$ \\
\hline 1 & 2,17 & 0,11 & 2,27 \\
2 & 2,11 & 0,13 & 2,21 \\
3 & 2,13 & 0,12 & 2,23 \\
\hline
\end{tabular}

Keterangan= H' (Indeks Keanekaragaman), C' (IndeksDominansi), E' (Indeks Kemerataan)

\section{Parameter Pendukung Makroinvertebrata}

Hasil pengukuran faktor fisika sesuai dengan msaing-masing parameter, suhu memiliki rentang $25^{\circ} \mathrm{C}-26^{\circ} \mathrm{C}$, kecerahan memiliki rentang $59 \mathrm{~cm}-130 \mathrm{~cm}$, kecepatan arus memiliki rentang 2 $\mathrm{m} / \mathrm{dt}_{-} 2,8 \mathrm{~m} / \mathrm{dt}$, kedalaman memiliki rentang $59 \mathrm{~cm}$ $130 \mathrm{~cm}$, TDS memiliki rentang $20 \mathrm{mg} / \mathrm{L}-64 \mathrm{mg} / \mathrm{L}$ dan TSS memiliki rentang $30 \mathrm{mg} / \mathrm{L}-84 \mathrm{mg} / \mathrm{L}$. pengukuran faktor kimia sesuai dengan masingmasing parameter, derajat keasaman $(\mathrm{pH})$ memiliki rentang 7,5-7,85, oksigen terlarut (DO) memiliki rentang 4,1 mg/L - 4,34 mg/L, karbondioksida bebas $\left(\mathrm{CO}_{2}\right) \quad 3,96 \mathrm{mg} / \mathrm{L} \quad-7,92 \mathrm{mg} / \mathrm{L}$. Kedalaman pada stasiun kedua memiliki kedalaman yang lebih tinggi dari stasiun pertama dan ketiga yaitu dengan kedalaman $130 \mathrm{~cm}$. Faktor fisika lainnya yang lebih tinggi dari pengukuran stasiun lainya adalah TDS dan TSS. Hasil pengukuran TDS pada stasiun ketiga lebih tinggi dari stasiun pertama dan kedua, dengan nilai 64 $\mathrm{mg} / \mathrm{L}$, sedangkan TSS pada stasiun pertama lebih tinggi dibandingkan stasiun kedua dan stasiun ketiga, dengan nilai $84 \mathrm{mg} / \mathrm{L}$ (Tabel 5).

Tabel 5. Hasil Pengukuran Parameter Fisika dan Kimia Sungai Mentuka

\begin{tabular}{|c|c|c|c|c|c|c|}
\hline \multirow{2}{*}{ Parameter uji } & \multirow{2}{*}{ satuan } & \multicolumn{2}{|c|}{ Kelas mutu air } & \multicolumn{3}{|c|}{ Hasil uji } \\
\hline & & II & III & S1 & S2 & $\mathbf{S 3}$ \\
\hline Parameter Fisika & & & & & & \\
\hline Suhu air & ${ }^{\circ} \mathrm{C}$ & $\begin{array}{c}\text { Deviasi } \\
3\end{array}$ & Deviasi 3 & 25 & 25 & 26 \\
\hline Kecerahan & $\mathrm{Cm}$ & - & - & 101 & 130 & 59 \\
\hline Kecepatan arus & $\mathrm{m} / \mathrm{dt}$ & - & - & 2,4 & 2,8 & 2 \\
\hline Kedalaman & $\mathrm{Cm}$ & - & - & 101 & 130 & 59 \\
\hline Total dissolved solid (TDS) & $\mathrm{mg} / \mathrm{L}$ & 1000 & 1000 & 20 & 36 & 64 \\
\hline Total supended solid (TSS) & $\mathrm{mg} / \mathrm{L}$ & 50 & 400 & 84 & 30 & 42 \\
\hline $\begin{array}{l}\text { Kimia Parameter } \\
\text { Derajat Keasaman }\end{array}$ & $\mathrm{pH}$ & 6-9 & $6-9$ & 7,5 & 7,85 & 7,8 \\
\hline Oksigen terlarut (DO) & $\mathrm{mg} / \mathrm{L}$ & 4 & 3 & 4,34 & 4,26 & 4,1 \\
\hline Karbondioksida bebas $\left(\mathrm{CO}_{2}\right)$ & $\mathrm{mg} / \mathrm{L}$ & ـ & _. & 6,6 & 7,92 & 3,96 \\
\hline
\end{tabular}

Keterangan: S 1-3 stasiun 1-3, Kelas Mutu air PP No 82 tahun 2001, - tidak ada nilai ambang batas

\section{Pembahasan}

\section{Komposisi Genus Makroinvertebrata}

Makroinvertebrata yang ditemukan di Sungai Mentuka Desa Pantok Kecamatan Nanga Taman, paling banyak ditemukan dari Genus Baetis dengan jumlah 52 individu. Hal ini dikarenakan pada aliran Sungai Mentuka memiliki banyak hamparan batuan. Batuan merupakan substrat dari Genus Baetis. Menurut Nangin et al., (2015) anggota Genus Baetis dapat ditemukan pada sungai-sungai berbatu yang belum tercemar dan keberadaannya merupakan bioindikator kualitas perairan bersih.

Anggota Genus Baetis menyukai suhu air yang rendah berkisar antara $25-26^{\circ} \mathrm{C}$. Pada daerah sekitar Sungai Mentuka tidak ditemukan adanya aktivitas penebangan liar yang akan berdampak pada Degradasi tanah yang akan menyebabkan sedimentasi dan menurunkan kualitas air. Baetis adalah kelompok dari Ordo Ephemeroptera. Ordo Ephemeroptera ini tidak toleran terhadap kualitas air yang rendah (Gooderham, 1998, dalam Mahajoeno 2001).

Genus yang paling sedikit ditemukan pada penelitian ini adalah Genus Acroneuria dari anggota famili Perlidae yang berasal dari Ordo Plecoptera. Anggota Genus ini ditemukan dengan total 30 individu. Hal ini dikarenakan Sungai Mentuka memiliki kualitas perairan yang dikatagorikan tercemar sedang. Kualitas perairan Sungai Mentuka dapat dilihat dari nilai indeks keanekaragaman yang tergolong sedang (Tabel 4). Genus Acroneuria adalah salah satu Anggota Ordo dari Plecoptera yang bisa hidup di perairan yang tercemar sedang. Penelitian Jhonatan et al., (2016) di Sungai Rombok Banangar Kabupaten Landak Kalimantan Barat juga mendapatkan anggota 
Genus Acroneuria dengan kelimpahan 44,4 ind $/ \mathrm{m}^{2}$ jumlah yang sedang dari kesebelas Genus yang ditemukan.

\section{Analisis Kelimpahan dan Frekuensi Kehadiran}

Makroinvertebrata yang ditemukan di Sungai Mentuka Desa Pantok Kecamatan Nanga Taman Kabupaten Sekadau memiliki nilai Kelimpahan tertinggi ditemukan di stasiun 1 pada bagian hulu Sungai dengan nilai kelimpahan 16,33 ind $/ \mathrm{m}^{2}$. Hal ini dikarenakan pada stasiun 1 memiliki kadar oksigen yang lebih tinggi sehingga mendukung kehidupan makroinverterbrata. Kehidupan Makroinvertebrata sangat dipengaruhi oleh kadar oksigen, semakin tinggi kadar oksigen didalam air maka kelimpahan Makroinvertebrata semakin tinggi, kedalaman pada stasiun 1 hanya $101 \mathrm{~cm}$, kedalaman juga mempengaruhi oksigen, semakin dalam suatu perairan maka kandungan oksigen semakin rendah, rendahnya kandungan oksigen akan menyebabkan penurunan kelimpahan makroinvertebrata. Diantari et al (2017) mengatakan kedalaman perairan 1,47 cm dengan tingkat kecerahan $100 \%$ banyak terdapat batuan besar dengan dasar kerikil dan pasir faktor yang mendukung kehidupan dari Ordo Plecoptera, Trichoptera, Emphemeroptera.

Kelimpahan Makroinvertebrata terendah ditemukan pada Stasiun 2 dengan nilai kelimpahan $12,78 \mathrm{Ind} / \mathrm{m}^{2}$. Stasiun 2 memiliki kelimpahan yang rendah dari stasiun pertama dan stasiun ketiga karena dipengaruh oleh adanya bendungan PLTA serta adanya pemukiman masyarakat. Fardiaz (1992) dalam Yasir (2017) mengatakan konsentrasi oksigen terlarut yamg terlalu rendah akan mengakibatkan biota yang membutuhkan oksigen akan mati. Kelimpahan relatif Makroinvertebrata di Sungai Mentuka Desa Pantok Kecamatan Nanga Taman Kabupaten Sekadau memiliki nilai kelimpahan yang sama yaitu $100 \%$. Frekuensi kehadiran pada semua Genus memiliki nilai yang sama dengan total nilai $100 \%$, hal ini disebabkan karena pada ketiga stasiun penelitian semua Genus ditemukan dalam setiap stasiun.

\section{Indeks Keanekaragaman dan Indeks Kemerataan}

Keanekaragaman Makroinvertebrata yang ditemukan di Sungai Mentuka Desa Pantok Kecamatan Nanga Taman Kabupaten Sekadau, mendapatkan nilai indeks Keanekaragaman tertinggi pada stasiun 1 dengan nilai Indeks Keanekaragaman $\left(\mathrm{H}^{\prime}\right)$ 2,17. Hal ini dikarenakan parameter fisika dan kimia mendukung kehidupan
Makroinvertebrata, di sekitar stasiun 1 tidak ditemukan pemukiman masyarakat. Nilai Indeks Keanekaragaman terendah terdapat pada stasiun 2 dengan nilai Indeks Keanekaragaman $\left(\mathrm{H}^{\prime}\right) 2,11$. Hal ini disebabkan oleh adanya aktivitas masyarakat di sekitar stasiun tersebut dan ditemukan adanya pemukiman masyarakat. Keberadaan pemukiman masyrakat disekitar Sungai, akan meningkatkan limbah Bungan yang berupa sampah organik maupun anorganik yang akan mencemari Sungai. Limbah yang masuk kedalaman Sungai akan meningkatkan kandungan $\mathrm{CO}_{2}$. Meningkatnya $\mathrm{CO}_{2}$ dalam perairan akan mempengaruh kelimpahan dan keanekaragaman makroinvertebrata. Rahman (2017) mengatakan dengan adanya pemukiman masyarkat dan adanya pembuangan sampah tidak beraturan dapat mempengaruhi kelimpahan dan keanekaragaman Makroinvertebrata.

Indeks Dominansi tertinggi ditemukan pada stasiun 2 dengan nilai 0,13 dan indeks dominansi terendah ditemukan pada stasiun 1 dengan nilai indeks dominansi 0,11 . Indeks dominansi berbanding terbalik dengan nilai indeks keanekaragaman, Semakin besar nilai indeks keragamaman maka nilai indeks dominansi semakin kecil, sehingga membuat nilai indeks kemerataan meningkat. Nilai indeks kemerataan tertinggi terdapat pada stasiun 1 dengan nilai indeks kemerataan 2,27. Nilai indeks kemerataan terendah terdapat pada stasiun 2 dengan nilai indeks kemerataan 2,21.

\section{Hubungan Nilai Kelimpahan Suatu Genus Dengan Faktor Lingkungan Perairan}

Berdasarkan hasil penelitian yang ditemukan pada ketiga stasiun, kelimpahan makroinvertebrata tertinggi adalah genus Baetis. Genus Baetis memiliki nilai kelimpahan 2,33 $\mathrm{Ind} / \mathrm{m}^{2}$, yang terdapat pada stasiun 3 dan kelimpahan terendah terdapat pada stasiun 2 dengan nilai kelimpahanya $1,55 \mathrm{ind} / \mathrm{m}^{2}$. Genus ini merupakan anggota dari Ordo Ephemeroptera dan berasal dari Family Baetidae. Anggota dari Genus ini memiliki cakar tarsal yang kuat dengan satu baris dentikel. Dengan adanya cakar tarsal yang kuat pada tungkai kakiny menyebabkan anggota genus ini bisa mempertahankan tubuhnya untuk tetap menempel terus pada substrat batuan. Hal ini karena kondisi perairan pada stasiun 3 memiliki air jernih dengan arus yang lemah $(2 \mathrm{~m} / \mathrm{dt})$ sehingga Baetis dapat menempel pada batuan dan sebaliknya pada stasiun 2 kecepatan arus air dan $\mathrm{pH}$ lebih 
kuat dari stasiun 1 dan stasiun 3 sehingga menyebabkan penurunan kelimpahan.

Genus Acroneuria merupakan anggota Famili Perlidae dan Ordo Plecoptera, genus ini memiliki nilai kelimpahan terendah yang Terdapat pada stasiun 3 dengan nilai kelimpahan 0,44 ind $/ \mathrm{m}^{2}$. Genus ini memiliki karakteristik kaki bersegmen, memiiki cakar pada bagian tungkai yang digunakan untuk mempertahankan tubuhnya pada substrat batuan. Larva Acroneuria habitat hidupnya berada pada air mengalir deras dan suhu rendah. Genus dari Acroneuria biasa banyak ditemukan di perairan yang tercemar ringan. Stasiun 3 memiliki TSS $(64 \mathrm{mg} / \mathrm{L})$ dan TDS (42 $\mathrm{mg} / \mathrm{L}$ ) hal ini yang menyebabkan Genus Acroneuria sedikit ditemukan, semakin tinggi nilai TSS dan TDS maka kelimpahan akan semakin rendah. Maula, (2018) mengatakan bahawa Acroneuria merupakan genus yang digunakan sebagai indikator biologis untuk pencemaran ringan. Sungai Mentuka tergolong Sungai dengan tingkat pencemaran sedang berdasarkan indeks keanekaragaman makroinvertebrata bentik.

\section{DAFTAR PUSTAKA}

Cummins, KW, 1975, Macroinvertebrates, in. Witton. B.A $(E d)$. Rivers Ecology. Blackwell Sceintific, London

Diantari, NPR, Ahyadi, H, Rohyani,IS, \& Suana, Iw, 2017, Keanekaragaman Serangga Ephemeroptera, Plecoptera, dan Trichoptera Sebagai Bioindikator Kualitas Perairan di Sungai Jangkok, Nusa Tenggara Barat, Jurnal Entomologi Indonesia, 14 (3): 135-142

Firdaus, M, 2012, Keanekaragaman Makroinvertebrata Air Pada Vegetasi Riparian Sungai Orde 1 Dan Orde 2 Di Sistem Sungai Maron Desa Seloliman Mojokerto, Skripsi Universitas Airlangga

Jhonatan, F, Setyawati, TR \& Linda ,R , 2016, Keanekaragaman Makrozoobentos di Aliran Sungai Rombok Banangar Kabupaten Landak Kalimantan Barat, Protobiont, 5 ,(1) : 39-45

Johan,TI \& Ediwarman, 2011, Dampak Penambangan Emas Terhadap Kualitas Air Sungai Singingi Di Kabupaten Kuantan
Singingi

Lingkungan, 5 (2) : 168-183

Kristianti, D, Yanti, AH \& Setyawati, TR, 2017, Jenis-Jenis Ikan Arus Deras Di Hulu Sungai Mentuka Kecamatan Nanga Taman Kabupaten Sekadau, Protobiont 6(3)

Leatemia, SPO, Wanggai, EC \& Talakua, S, 2016, Kelimpahan dan Keanekaragaman Makroinvertebrata Air Pada Kerapatan Vegetasi Riparian Yang Berbeda di Sungai Aimasi Kabupaten Manokwari, The Journal of fisheries Development 3 (1): 25 38

Lencioni, V, Bernabo, P, Vanin, S, Muro, PD \& Beltramini, M, 2008, Respiration Rate And Oxy-Regulatory Capacity In Cold Stenothermal Chironomids, Journal of Insect Physiology, 54 : 1337-1342

Mahajoeno, M, Efendi, M \& Ardiansyah, 2001, Keanekaragaman Larva Insekta Pada Sungai-Sungai Kecil di Hutan Jobolarangan, Jurnal Biodiversitas, 2 (2):133-139.

Maula, LH, 2018, Keanekaragaman Makrozoobentos Sebagai Bioindikator Kualitas Air Sungai Cokro Malang, Skripsi, Universitas Islam Negeri (UN) Maulana Malik Ibrahim Malang, Malang

Michael, P,1984, Metode Ekologi untuk Penyelidikan Lapangan dan Laboratorium. Universitas Indonesia Press. Jakarta

Munthe, YV, Aryawati, R, \& Isnaini, 2012, Struktur Komunitas dan Sebaran Fitoplankton di Perairan Sungsang Sumatera Selatan, Maspari Journal, 4 (1): 122-130.

Nangin, SR, Langoya, ML \& Katilia, DY, 2015, Makrozoobentos Sebagai Indikator Biologi Dalam Menentukan Kualitas Air Sungai Suhuyon Sulawesi Utara, Jurnal MIPA UNSRAT ONLINE, 4 (2): 165-168.

Needham, JG \& PR. Needham. 1964, A Guide to the Study of Fresh Water Biology. Fifth Edition, Revised and Enlarged. Holder-day Inc, San Fransisco. 
Odum, EP., 1993, Dasar-Dasar Ekologi, Edisi ke tiga, Gadjah Mada University Press, Yogyakarta.

Purwati, SU., 2015, Karakteristik Bioindikator Cisadane Kajian Pemanfaatan Makrobentik Untuk Menilai Kualitas Sungai Cisadane, Jurnal Ecolab 9 (2): 4759

Rahman, A, 2017, Pengunaan Indeks BMWPASPT Dan Parameter Fisika-Kimia Untuk Menentukan Status Kualitas Sungai Besar Kota Banjarbaru, Jurnal Biodidaktika 12 (1): 7-16

Ratih, I, Prihanta, W \& Susetyarini, RE, 2015, Inventarisasi Keanekaragaman Makrozoobentos Di Daerah Aliran Sungai Brantas Kecamatan Ngoro Mojokerto Sebagai Sumber Belajar Biologi SMA Kelas X, Jurnal Pendidikan Indonesia, $1(2): 158-169$.

Rinawati, Hidayat, D, Suprianto, R \& Dewi, PS, 2016, Penentuan Kandungan Zat Padat (Total Dissolve Solid Dan Total Suspended Solid) Di Perairan Teluk Lampung, Jurnal Analytical and Environmental Chemistry, 1(01):36-45

Salmin, 2005, Oksigen Terlarut (DO) Dan Kebutuhan Oksigen Biologi (BOD) Sebagai Salah Satu Indikator Untuk Menentukan Kualitas Perairan, Jurnal Oseana $x x x,(3): 21-26$.

Suhardjo, I, 2008, Degradasi Dasar Sungai, Teodolita, 9,(1):47-57

Yasir, AA, 2017, Struktur Komunitas Makrozoobenthos Pada Lokasi Dengan Aktivitas Berbeda di Perairan Sungai Tallo Kota Makassar, Skripsi UNIVERSITAS HASANUDDIN MAKASSAR.

Yeanny, MS, 2010, Perubahan Lingkungan Ekosistem Sungai Belawanan Terhadap Kualitas Air Dan Keanekaragaman Makrozoobentos Sebagai Bioindikator, Jurnal Biosfera, (1): 38-45 